\title{
The isolation and characterization of two Stenotrophomonas maltophilia bacteriophages capable of cross-taxonomic order infectivity
}

\author{
Danielle L. Peters ${ }^{1}$, Karlene H. Lynch ${ }^{1}$, Paul Stothard ${ }^{2}$ and Jonathan J. Dennis ${ }^{1 *}$
}

\begin{abstract}
Background: A rapid worldwide increase in the number of human infections caused by the extremely antibiotic resistant bacterium Stenotrophomonas maltophilia is prompting alarm. One potential treatment solution to the current antibiotic resistance dilemma is "phage therapy", the clinical application of bacteriophages to selectively kill bacteria.

Results: Towards that end, phages DLP1 and DLP2 (VB_SmaS-DLP_1 and VB_SmaS-DLP_2, respectively) were isolated against $S$. maltophilia strain D1585. Host range analysis for each phage was conducted using 27 clinical $S$. maltophilia isolates and 11 Pseudomonas aeruginosa strains. Both phages exhibit unusually broad host ranges capable of infecting bacteria across taxonomic orders. Transmission electron microscopy of the phage DLP1 and DLP2 morphology reveals that they belong to the Siphoviridae family of bacteriophages. Restriction fragment length polymorphism analysis and complete genome sequencing and analysis indicates that phages DLP1 and DLP2 are closely related but different phages, sharing $96.7 \%$ identity over $97.2 \%$ of their genomes. These two phages are also related to P. aeruginosa phages VB_Pae-Kakheti_25 (PA25), PA73, and VB_PaeS_SCH_Ab26 (Ab26) and more distantly related to Burkholderia cepacia complex phage KL1, which together make up a taxonomic sub-family. Phages DLP1 and DLP2 exhibited significant differences in host ranges and growth kinetics.
\end{abstract}

Conclusions: The isolation and characterization of phages able to infect two completely different species of bacteria is an exciting discovery, as phages typically can only infect related bacterial species, and rarely infect bacteria across taxonomic families, let alone across taxonomic orders.

Keywords: Stenotrophomonas maltophilia, Bacteriophage, Phage, DNA, Genomics, Phage genome, Delayed lysis, Broad-host-range

\section{Background}

The rise in antibiotic resistance amongst bacterial pathogens around the world is causing alarm, with the possibility of a "post-antibiotic era" in the 21st century [1]. One broadly antibiotic-resistant bacterium that is increasing in prevalence in nosocomial and community-acquired infections is Stenotrophomonas maltophilia. Some of the infections associated with S. maltophilia include pneumonia, bacteremia, meningitis, endocarditis, catheter-related bacteremia/septicemia and acute exacerbations in patients

\footnotetext{
*Correspondence: jon.dennis@ualberta.ca

'Department of Biological Sciences, 6-065 Centennial Centre for Interdisciplinary Science, University of Alberta, Edmonton, AB T6G 2E9, Canada

Full list of author information is available at the end of the article
}

with cystic fibrosis and chronic obstructive pulmonary disease $[2,3]$. Preventing infections caused by this bacterium is difficult, as S. maltophilia is ubiquitous in the environment and can be easily spread in nosocomial settings by health care providers and cough-generated aerosols [2, 4]. Treatment of S. maltophilia infections is problematic due to its innate resistance to a broad array of antibiotics such as trimethoprim/sulfamethoxazole, $\beta$-lactams, macrolides, cephalosporins, fluoroquinolones, aminoglycosides, carbapenems, chloramphenicol, tetracyclines and polymyxin. New treatment strategies are thus required in order to successfully combat this extremely drug-resistant bacterium.

One promising treatment strategy is the clinical application of bacteriophages, also known as phage therapy, 
to selectively kill infecting bacteria [5-10]. Phage therapy has been used for nearly a century in some Eastern European countries, but was largely abandoned in the West during the 1940s due to the advent of broadspectrum antibiotics. However, with the rise in antibiotic resistance threatening the traditionally effective treatment of bacterial infections, rigorous research into the efficacious use of phage therapy has been renewed. Recent studies utilizing phage therapy in animal models [11-17] and human clinical trials [18-20] have shown that phages can be a successful treatment option. In order to obtain FDA approval for the clinical use of phages, proof is required to show that phage genomes do not encode toxins or other undesirable genes that could potentially enhance bacterial virulence [21]. Therefore, all S. maltophilia-specific phages that are to be considered for use in a phage therapy strategy must be fully characterized through complete genome sequencing and analysis to ensure they are safe for use in human clinical trials.

Recent research has led to the isolation and characterization of several different $S$. maltophilia phages, including a jumbo phage phiSMA5 (with a genome of approximately $250 \mathrm{~kb}$ in length, [22]), a filamentous phage phiSMA9 with a genome size of $6.9 \mathrm{~kb}$ encoding only seven genes, but one of these being a zot toxin [23], a virulent phage Smp14 that exhibits homology to phage T4 [24], a lytic phage IME13 with an unusually large burst size [25], a T7-like phage IME15 specific to S. maltophilia [26], a P2-like phage Smp131 whose genome exhibits sequence homology to prophages in Xanthomonas species [27], and three other novel, small filamentous phages phiSMA 6, phiSMA7 and phiSHP1 [28, 29]. Twenty-two phages specific for different Stenotrophomonas species, including the well-characterized temperate phage S1, have also recently been isolated [30]. Additional pertinent research has shown that non-interactive Lactococcus phages can easily penetrate the biofilms produced by $S$. maltophilia [31, 32]. Here we describe the isolation and characterization of two novel S. maltophilia phages DLP1 and DLP2. These phages are related to three previously characterized Pseudomonas aeruginosa phages and have the unusual characteristic of cross-taxonomic order infectivity, the ability to use strains of both $S$. maltophilia and $P$. aeruginosa as hosts for phage propagation.

\section{Results and discussion}

Isolation, host range and morphology

Using S. maltophilia strain D1585, phages DLP1 and DLP2 were isolated from Red Deer River sediment and soil planted with blue flax (Linum lewisii), respectively. In contrast to the characterized S. maltophilia phages isolated from clinical settings, sewage samples and lysogenic bacteria [22-30], DLP1 and DLP2 are the first phages to be isolated from sediment and soil.

Phage DLP1 exhibits a unique plaque development that was previously identified in phages KL1 and AH2 that target bacteria of the Burkholderia cepacia complex [33]. As with KL1 and AH2, stocks of DLP1 can be concentrated (up to $10^{10}$ plaque forming units $[\mathrm{PFU}] / \mathrm{ml}$ ), but use of such high titre stocks results in plates with no plaques. Instead, when lower titres $\left(10^{7} \mathrm{PFU} / \mathrm{ml}\right.$ or less $)$ are used, and the plates are incubated at $30{ }^{\circ} \mathrm{C}$ for at least $24 \mathrm{~h}$, DLP1 plaque development occurs (Fig. 1). Individual plaques for DLP1 are turbid with no distinct boarders and a diameter of $0.4-1 \mathrm{~mm}$, averaging $0.7 \mathrm{~mm}$. This contrasts the plaque development of phage DLP2, which produces clearing at high titres and clearly defined plaques at lower titres following $16 \mathrm{~h}$ incubation at $30{ }^{\circ} \mathrm{C}$ (Fig. 1). Plaque sizes for DLP2 are clear with distinct boarders and a diameter $0.2-0.8 \mathrm{~mm}$, averaging $0.4 \mathrm{~mm}$.

DLP1 and DLP2 are classified in the order Caudovirales and the family Siphoviridae due to their morphological characteristics observed using electron microscopy. The DLP1 phage has a long, non-contractile tail of approximately $175 \mathrm{~nm}$ in length and a capsid size of approximately $70 \mathrm{~nm}$ in diameter (Fig. 2a). Phage DLP2 is larger, with a non-contractile tail of approximately $205 \mathrm{~nm}$ and a capsid size of approximately $70 \mathrm{~nm}$ in diameter (Fig. 2b).

Both DLP1 and DLP2 have a moderate host range within the $S$. maltophilia strains tested, with the ability to infect eight and nine out of 27 strains, respectively (Table 1). Both phages also have a unique ability to infect across bacterial taxonomic orders, with each phage capable of infecting two separate $P$. aeruginosa strains each (Table 2, Additional file: 1Table S1). This is an interesting finding, as bacteriophages are typically thought to be relatively species specific. However, there are examples of bacteriophages that have been shown to lyse bacteria of different genera. For example, some phages originally discovered to infect one genus of Cyanobacteria, have also been shown to be able to lyse other Cyanobacteria genera [34-36]. Confirmation of successful DLP1 and DLP2 infection and lysis of $P$. aeruginosa strains was confirmed with the use of PCR (Fig. 3).

\section{Genome characterization}

Genomic analysis of phages DLP1 and DLP2 reveals they are closely related phages. Initially, a comparison of restriction fragment length polymorphisms (RFLPs) of DLP1 and DLP2 EcoRI-digested genomic DNA shows similar banding patterns with slight band differences between 0.85-1, 2-3 and $5 \mathrm{kbp}$ (Fig. 4). DLP1 and DLP2 similarity was confirmed by the results of the whole genome sequencing using the Illumina platform (discussed below). A genome map for DLP1 and DLP2 (Fig. 5) shows the modular similarity of the two phages, as well 


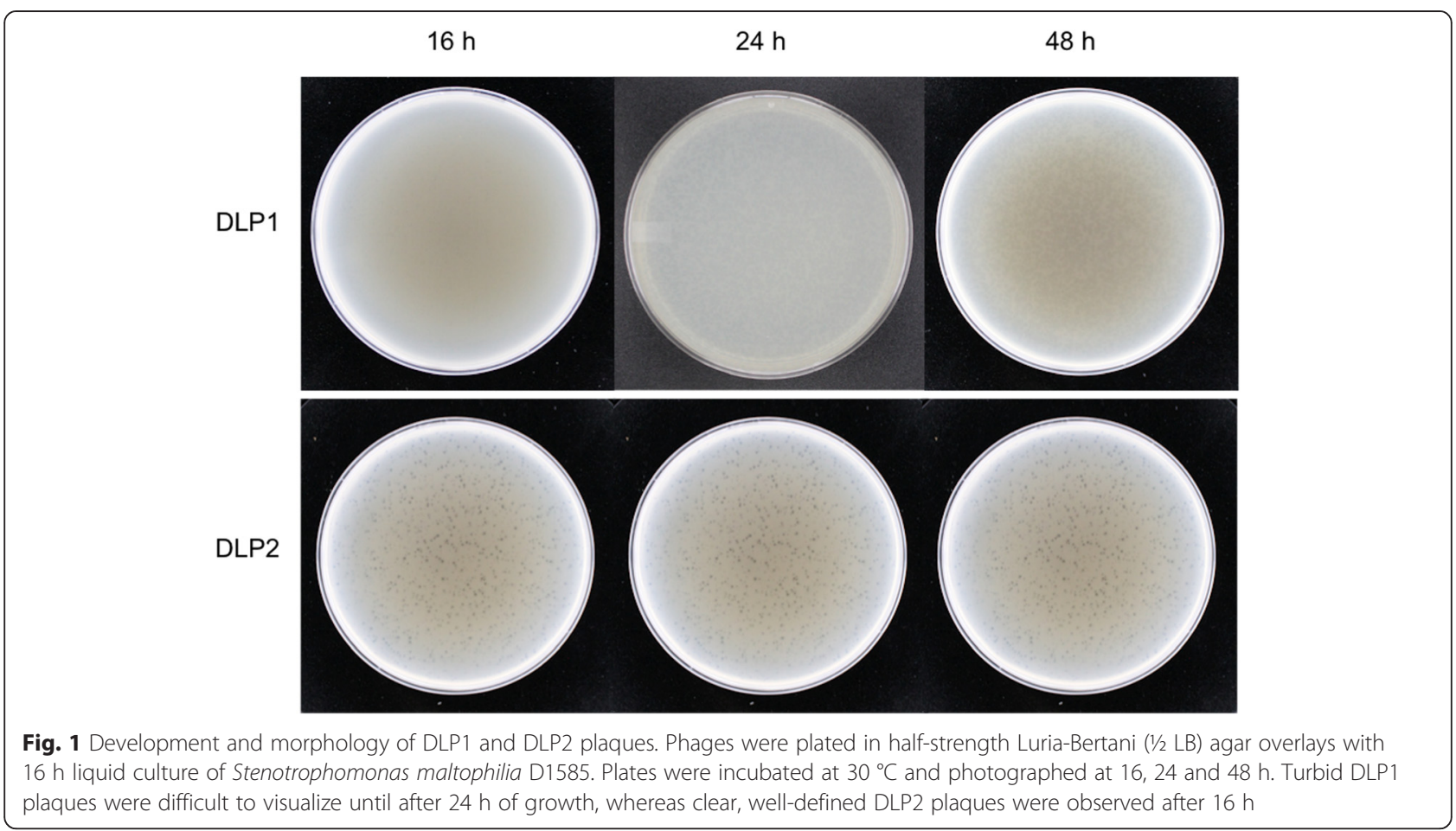

as their genetic similarity with respect to their genes and genome sizes. However, complete genome sequencing also demonstrates the crudeness of RFLP analysis. The DLP1 genome contains 31 EcoRI sites, whereas the DLP2 genome possesses 32 EcoRI sites. Phage DLP1 possesses five DNA insertions of 29 bp in EcoRI fragment 6869-9910, $40 \mathrm{bp}$ in fragment 9910-10,628, $50 \mathrm{bp}$ in fragment $12,987-13,729,129 \mathrm{bp}$ in fragment 24,500 -
27,657 and 118 bp in fragment 34,709-39,879. Phage DLP2 possesses three DNA insertions of $40 \mathrm{bp}$ in EcoRI fragment $10,559-11,971,87 \mathrm{bp}$ in fragment 14,00314,999, and 5 bp in fragment 29,984-31,617. In addition, phage DLP2 has an extra EcoRI site at base pair 3345 due to a point mutation. Phages DLP1 and DLP2 were found to be $96.7 \%$ identical over $97.2 \%$ of their genomes. However, this comparison still denotes considerable
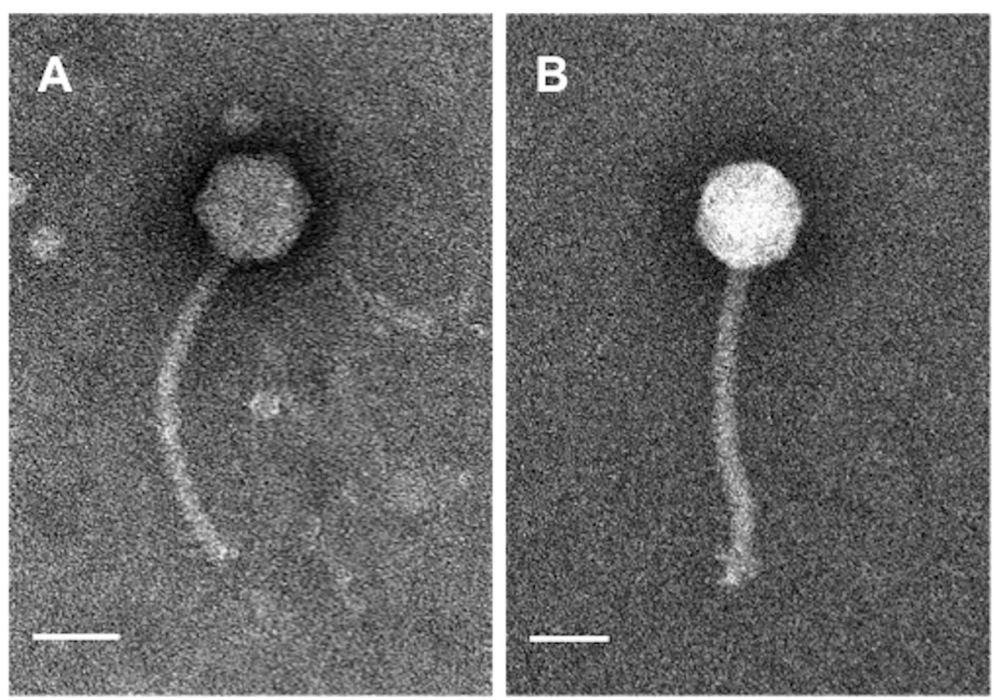

Fig. 2 DLP1 (a) and DLP2 (b) phage morphology. Phages were stained with $4 \%$ uranyl acetate and visualized at 180,000-fold magnification by transmission electron microscopy. Scale bars represent $50 \mathrm{~nm}$. Both Siphoviridae family phages were of similar size, although the tail of DLP1 $(175 \mathrm{~nm})$ was shorter than that of DLP2 $(205 \mathrm{~nm})$ 
Table 1 Host range analysis of DLP1 and DLP2 against Stenotrophomonas maltophilia clinical isolates

\begin{tabular}{|c|c|c|}
\hline \multirow{2}{*}{$\begin{array}{l}\text { S. maltophilia } \\
\text { strain }\end{array}$} & \multicolumn{2}{|l|}{ Phage } \\
\hline & DLP1 & DLP2 \\
\hline 101 & + & + \\
\hline 102 & - & + \\
\hline 103 & + & + \\
\hline 152 & - & - \\
\hline 155 & - & - \\
\hline 174 & - & - \\
\hline 176 & - & - \\
\hline 213 & + & + \\
\hline 214 & - & - \\
\hline 217 & - & - \\
\hline 218 & + & - \\
\hline 219 & - & - \\
\hline 230 & - & - \\
\hline 236 & + & + \\
\hline 242 & + & + \\
\hline 249 & + & + \\
\hline 278 & - & - \\
\hline 280 & - & ++++ \\
\hline 282 & - & - \\
\hline 287 & - & - \\
\hline 446 & - & - \\
\hline 667 & - & - \\
\hline $\mathrm{D} 1585^{\mathrm{a}}$ & ++++ & ++++ \\
\hline $\mathrm{D} 1571^{\mathrm{a}}$ & - & - \\
\hline D1614 & - & - \\
\hline $\mathrm{D} 1576^{\mathrm{a}}$ & - & - \\
\hline $\mathrm{D} 1568^{\mathrm{a}}$ & - & - \\
\hline
\end{tabular}

- , No sensitivity to phage; + , plaques at $10^{-2} ;++$, clearing at $10^{-2} ;+++$, plaques at $10^{-4} ;++++$, plaques at $10^{-6}$

alsolates from the Canadian Burkholderia cepacia complex Research Referral Repository

variation between the two phage genomic sequences. A BLASTN comparison indicates that the two genomes share 40,317 identical base pairs out of 41,687 aligned base pairs (1200 base pairs unaligned), with 166 gaps. The similarity of DLP1 and DLP2 to each other, and to their closest relative Pseudomonas phage vB_Pae-Kakheti25 (informally PA25), is illustrated in Fig. 6, a Circos plot of a NUCmer comparison of the three phages.

The DLP1 genome is 42,887 base pairs (bp) in length, with a GC content of $53.7 \%$. DLP1 is predicted to encode 57 proteins with the most common start codon being ATG, although a TTG start codon is used for gp19, gp37 and gp41 (Table 3, Fig. 5). Besides phage DLP2, phage DLP1 is most closely related to the siphovirus
Table 2 Host range analysis of DLP1 and DLP2 against Pseudomonas aeruginosa strains

\begin{tabular}{|c|c|c|}
\hline \multirow{2}{*}{$\begin{array}{l}\text { P. aeruginosa } \\
\text { strain }\end{array}$} & \multicolumn{2}{|l|}{ Phage } \\
\hline & DLP1 & DLP2 \\
\hline PA01 & ++ & - \\
\hline HER1004 & - & +++ \\
\hline HER1012 & - & - \\
\hline 14,715 & - & ++ \\
\hline Utah3 & - & - \\
\hline Utah4 & - & - \\
\hline 14,655 & - & - \\
\hline 6106 & - & - \\
\hline pSHU-OTE & - & - \\
\hline $\mathrm{D} 1606 \mathrm{D}^{\mathrm{a}}$ & - & - \\
\hline $\mathrm{D} 1615 \mathrm{C}^{\mathrm{a}}$ & - & - \\
\hline D1619M ${ }^{a}$ & - & - \\
\hline $\mathrm{D} 1620 \mathrm{E}^{\mathrm{a}}$ & - & - \\
\hline $\mathrm{D} 1623 \mathrm{C}^{\mathrm{a}}$ & - & - \\
\hline ENV003 ${ }^{a}$ & - & - \\
\hline ENV009 ${ }^{a}$ & +++ & - \\
\hline $\mathrm{FC} 0507^{\mathrm{a}}$ & - & - \\
\hline R285 & - & - \\
\hline 14,672 & - & - \\
\hline $\begin{array}{l}-, \text { No sensitivit } \\
\text { plaques at } 10^{-} \\
\text {alsolates from } \\
\text { Referral Reposi }\end{array}$ & $\begin{array}{l}10^{-2} ; \\
\text { сера }\end{array}$ & \\
\hline
\end{tabular}

Pseudomonas phage vB_Pae-Kakheti25 (PA25) (Fig. 6) [37]. DLP1 and PA25 phages are similar with respect to genome length $(42,844$ bp for PA2 5 and 42,887 bp for DLP1), GC content (53.7\% for PA25 and DLP1) and predicted number of proteins (58 for PA25 and 57 for DLP1) [37]. BLASTN comparison of DLP1 and PA25 shows a $98 \%$ identity over $94 \%$ of the genome. The genome of DLP1 also shows high similarity to phages PA73 (98\% identity over $92 \%$ of the genome) [38] and vB_PaeS_SCH_Ab26 (Ab26) (96\% identity over $92 \%$ of the genome) [37]. Again, this represents a significant amount of genetic variation, with 145 gaps required to complete the genomic alignment with PA25, 144 gaps required to align PA73, and 220 gaps required to align Ab26, suggesting that although these phages belong to the same family, they are not merely variants of one another. The predicted proteins of DLP1 are similar to those found in phages PA25, PA73 and Ab26; though DLP1 proteins gp32, gp45 and gp48 are unique in that they are not similar to any proteins found in PA25, PA73 and Ab26 (Table 3). The DLP1 protein gp32 is related to gp055 of the Erwinia phage vB_EamP-S6. The gp45 protein is related to the hypothetical protein X805_23910 of Sphaerotilus natans subsp. natans DSM 


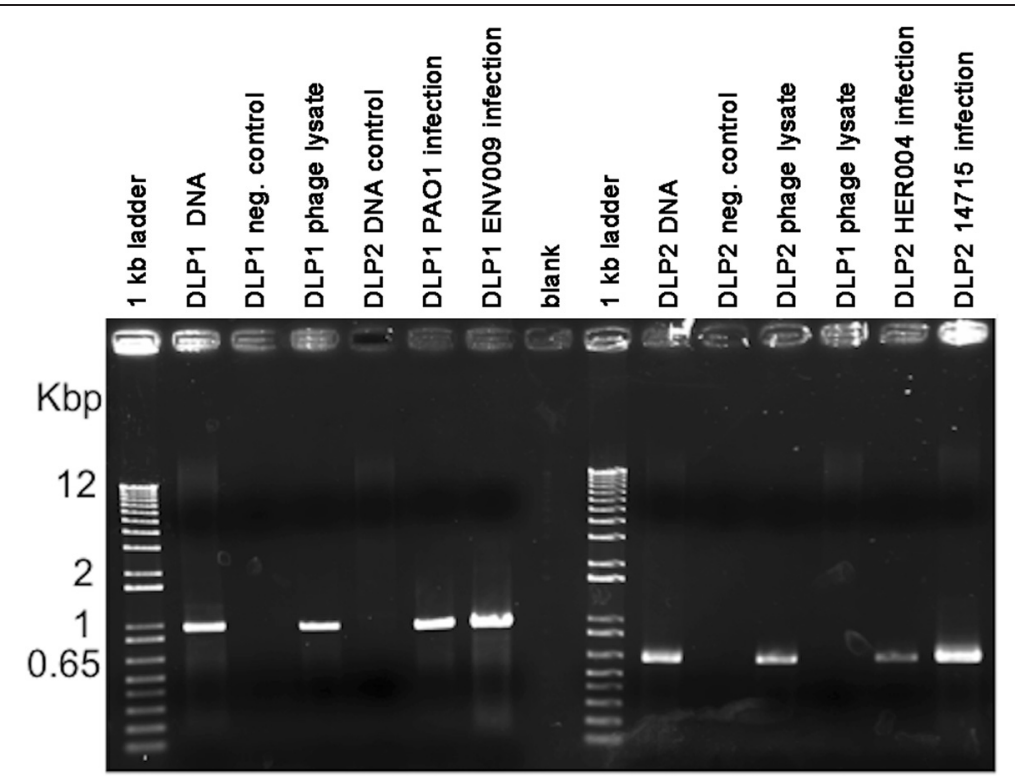

Fig. 3 PCR confirmation of $P$. aeruginosa infections by DLP1 and DLP2. Lanes 1 and 9: 1 Kb Plus DNA ladder (Invitrogen), lane 2: DLP1 phage DNA, lane 3: DLP1 negative control, lane 4: DLP1 phage lysate, lane 5: DLP2 phage DNA, lane 6: DLP1 phage lysate from PA01 infection, lane 7: DLP1 phage lysate from ENV009 infection, lane 8: blank, lane 10: DLP2 phage DNA, lane 11: DLP2 negative control, lane 12: DLP2 phage lysate, lane 13: DLP1 phage lysate, lane 14: DLP2 phage lysate from HER004 infection, lane 15: DLP2 phage lysate from 14,715 infection. The size of the markers (in Kbp) is shown on the left

6575 , which is a filamentous bacterium known to contribute to the stability of Pseudomonas sp. colonies at low concentrations [39]. The Vsr endonuclease encoded by gp48 is most homologous to a gene found in the Burkholderia phage KL1 [33].

The DLP2 genome is 42,593 bp in length, with a GC content of $53.7 \%$. DLP2 is predicted to encode 58 proteins with the most common start codon being ATG, although a TTG start codon is used for gp19 and gp37, and a GTG start codon is used for gp43 and gp55 (Table 4, Fig. 5). Phage DLP2 is also related to Pseudomonas phage PA25 (Fig. 6). These two phages are similar with respect to genome length $(42,844$ bp for PA25 and 42,593 for DLP2), GC content (53.7\% for PA25 and DLP2) and predicted number of proteins (58 for PA25 and DLP2) [40]. BLASTN comparison of the DLP2 and PA25 genomes shows a $97 \%$ identity over $95 \%$ of the genome. The BLASTN results also reveals DLP2 to be similar to Pseudomonas phages PA73 (98\% identity over $93 \%$ of genome) [38] and Ab26 (97\% identity over $90 \%$ of the genome) [37]. Phage DLP2 gene content differs from phages PA25, PA73 and Ab26 in predicted proteins gp39 and gp45 (Table 4). DLP2 protein gp39 is most closely related to the uncharacterized protein MAM_066 of the Serratia phage ФMAM1. Similar to DLP1, the DLP2 gp45 protein is related to the hypothetical protein X805_23910 of Sphaerotilus natans subsp. natans DSM 6575.

\section{Analysis of modules}

The proteins identified in DLP1 and DLP2 can be classified into three general categories: lysis, virion morphogenesis (including DNA packing and capsid/tail morphogenesis) and DNA replication/repair. The ORFs of DLP1 and DLP2 are syntenic, and the predicted proteins are similar with only a few variations from each other (Tables 3 and 4), yet these two phages exhibit two completely different plaque development characteristics (Fig. 1). It is also of interest to note that no genes encoding known or putative virulence factors were discovered in the genomes of phages DLP1 and DLP2, or any other related phages in this family.

\section{Lysis}

Genes putatively encoding the lysis proteins holin, lysin, Rz, Rz1 and a hypothetical protein have been identified in DLP1. A BLASTP search of predicted protein gp1 shows that it is similar to a phage protein family found in lysis cassettes that was identified in phage PA25. A BLASTP search also showed gp2 to be a putative holin protein similar to those identified in PA25 and PA73. Analysis of this gp2 protein with TMHMM revealed it has two transmembrane domains; thus, gp2 is a predicted to be a class II holin [40]. Gene gp3 is nearly identical to the endolysin of PA25. Gp4 and gp5 proteins are similar to the $\mathrm{Rz}$ protein of Ab26 and Rz1 of PA25 respectively. The $\mathrm{Rz}$ protein is a class II inner membrane 


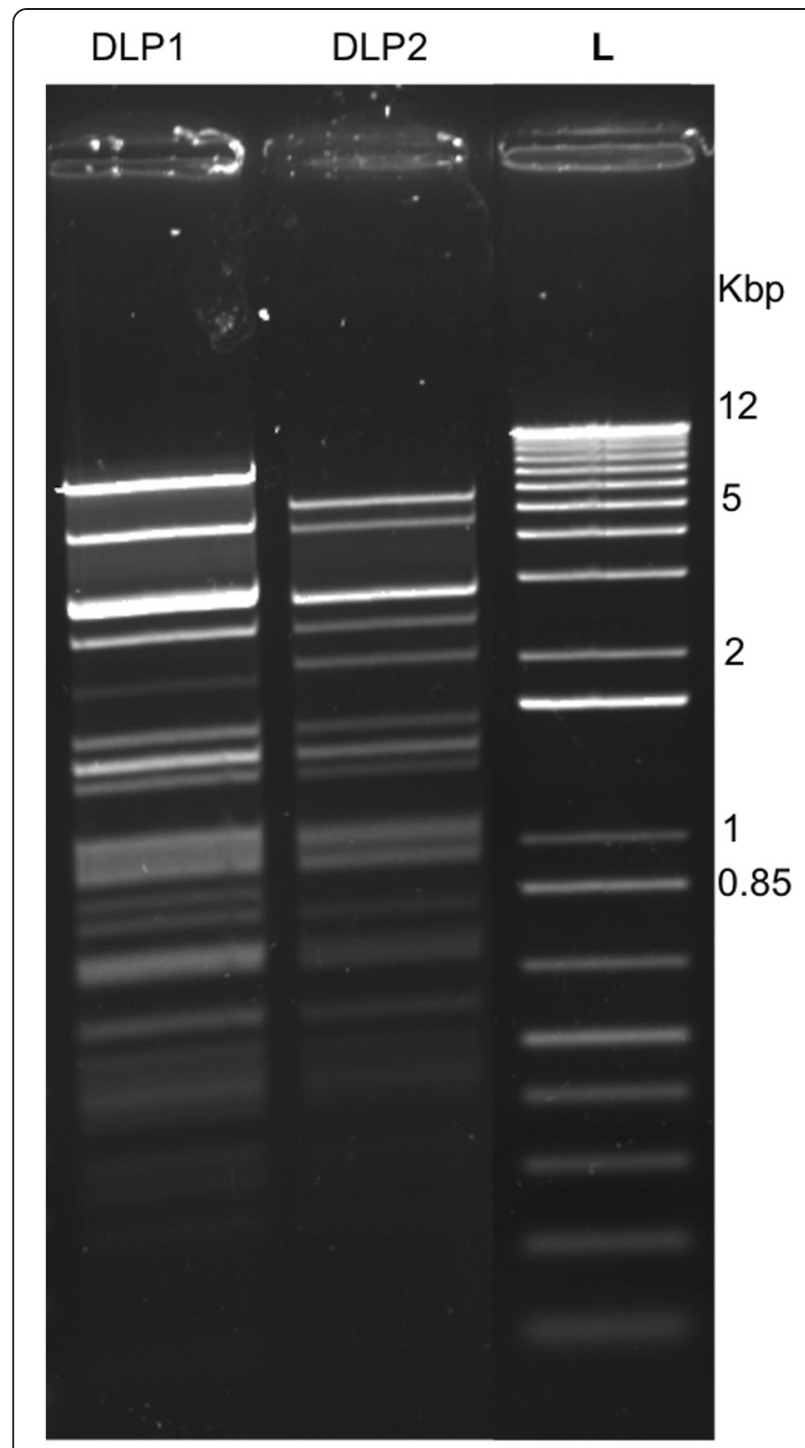

Fig. 4 Restriction fragment length polymorphism of DLP1 and DLP2 genomic DNA. $1 \mu \mathrm{g}$ of phage genomic DNA was digested 5 min with EcoRl and separated on a $1 \%$ agarose gel. L: $1 \mathrm{~Kb}$ Plus DNA Ladder (Invitrogen). Several differences in banding pattern between the genomic DNAs isolated from the two phages is apparent protein with an N-terminal domain and Rz1 is a prolinerich outer membrane lipoprotein [41]. The Rz/Rz1 proteins contribute to lysis by fusing to the inner and outer membranes following holin and endolysin activity to facilitate phage release [42]. The gp4 protein is predicted to contain a single $\mathrm{N}$-terminal transmembrane domain, a characteristic of Rz proteins [40, 43]. LipoP analysis of gp5 shows a signal peptidase II cleavage site between amino acids 20 and 21, resulting in a 73 amino acid protein with 7 proline residues (9.6 \% proline) [44].

The lysis predicted proteins identified in DLP2 are similar to those also identified in phage DLP1. However, there are also some differences. The gp3 of DLP2 is most closely related to ORF003 of PA73 and also the endolysin protein in PA25. Like DLP1, gp4 of DLP2 is similar to the Rz protein of phage Ab26. Although DLP2 gp5 required manual annotation, BLASTP analysis showed it is most closely related to Rz1 of Ab26, rather than phage PA25. However, LipoP analysis revealed the identical signal peptidase II cleavage site as for phage DLP1 gp5. Analysis of the lysis module for DLP1 and DLP2 did not reveal why phage DLP1 exhibits delayed plaque development when compared to phage DLP2. One hypothesis is that gp32 of DLP1, encoding a hypothetical protein not found in DLP2 (most closely related to gp055 of Erwinia phage vB_EamP-S6), contributes to the delayed plaque development of DLP1. However, until a definitive function for the DLP1 gp32-encoded protein can be established, this hypothesis remains unproven.

\section{Virion morphogenesis}

As discussed above, DLP1 is closely related to phage DLP2, and phages PA25, Ab26 and PA73, whose proteins are generally uncharacterized. BLASTP analysis of the 20 genes involved in virion morphogenesis in DLP1 identified 13 genes with putative functions: two involved in DNA packaging, four involved in capsid morphogenesis and seven involved in tail morphogenesis. The DNA packaging proteins gp6 (small terminase subunit) and gp7 (large terminase subunit) are similar to the small terminase subunit of PA25 and large terminase subunit of Ab26 respectively. Protein gp8 shares a $98 \%$ identity to the portal protein of Ab26. Although gp9 shares $100 \%$ identity to uncharacterized ORF008 of PA73, it

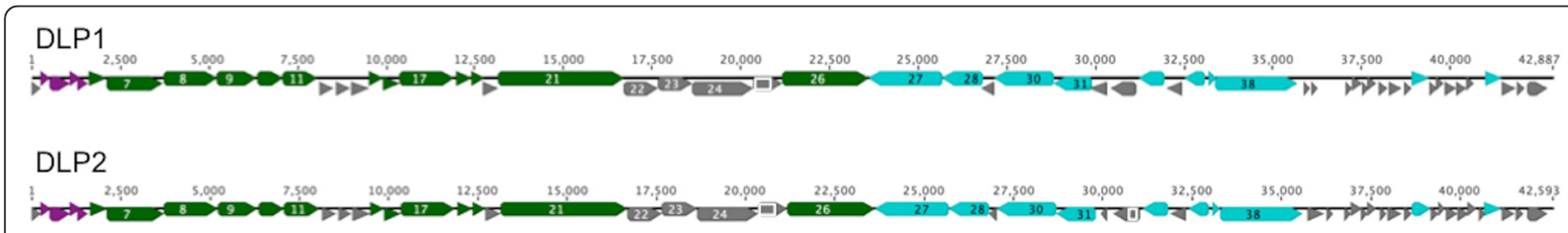

Fig. 5 Genome maps of DLP1 and DLP2. The scale (in kbp) is shown above the DLP1 and DLP2 genomic maps. The assigned function of the predicted proteins encoded by each open reading frame is as follows: grey - unknown function; purple - lysis; green - virion morphogenesis; blue - DNA replication/repair. Numbers within the larger ORFs relate to gene product number 


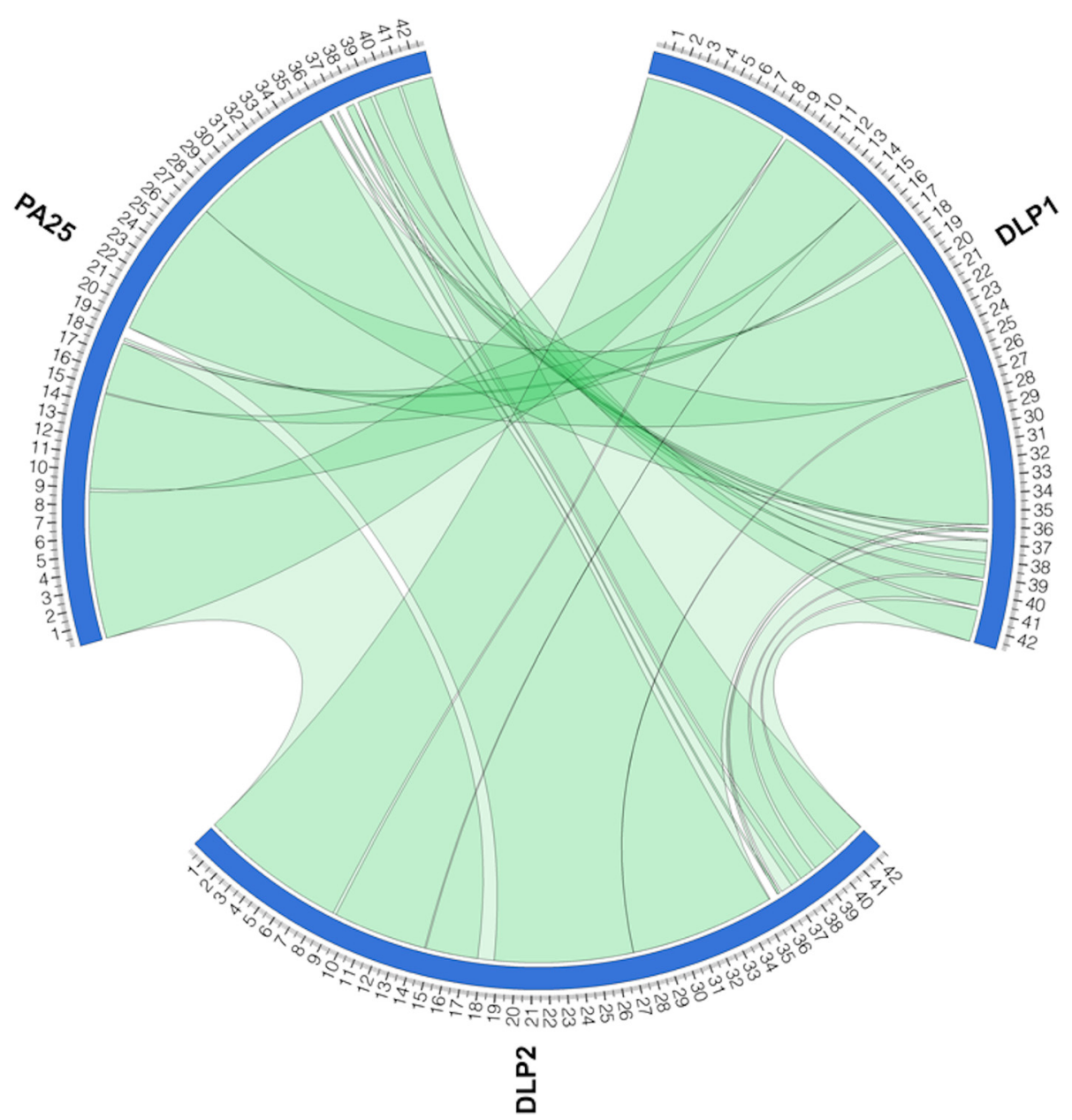

Fig. 6 Circos plot of genomes from phages DLP1, DLP2 and vB_Pae-Kakheti25 (PA25) NUCmer comparisons. Green ribbon indicates regions of similarity between the three genomes at the nucleotide level. The scale (in $\mathrm{kbp}$ ) is shown on the periphery of the plot for each phage. NUCmer parameters: breaklen $=200$, maxgap $=90$, mincluster $=65$, minmatch $=20$

has been assigned a putative function due to its high similarity to the F-like head morphogenesis protein of Ab26 (Table 3). Gp10 shares $100 \%$ identity to the scaffold protein of PA25. The gp11 is most similar to ORF010 of PA73, but its high similarity to the major capsid protein of Ab26 has allowed a putative function to be assigned to this protein (Table 3). The seven proteins involved in tail morphogenesis are gp15 (head-tail joining protein), gp16 (minor tail protein), gp17 (major tail protein), gp18 (tail chaperonin), gp19 (tail chaperonin), gp21 (tape measure protein) and gp26 (central tail hub). Both gp15, closely related to the virion protein of Ab26, and gp16, closely related to ORF015 of PA73, have been assigned putative functions due to their similarities to the head-tail joining protein and minor tail protein of Burkholderia phage KL1 respectively (Table 3) [33]. Protein gp17 shares a $99 \%$ identity to the major tail protein of PA25. Gp17 is $100 \%$ identical to ORF017 of PA73, but has been assigned the putative function of tail chaperonin due to its similarity to Ab26 tail chaperonin. Like gp17, gp18 is predicted to be a tail chaperonin protein, and has $100 \%$ identity to the PA25 tail chaperonin protein. Both gp21 and gp26 are closely related to the tape measure protein and central tail hub of PA25, respectively. Analysis of DLP2 with BLASTP revealed the virion morphogenesis proteins are nearly identical to those of DLP1, with only minor differences (Table 4).

\section{DNA replication and repair}

DLP1 and DLP2 have seven and eight identified proteins, respectively, identified to be involved in DNA replication and repair at the same gene position: DNA polymerase (gp27), replicative clamp (gp28), RecB exonuclease (gp31 DLP2 only), RecA (gp34), MazG (gp36), replicative primase/helicase (gp39), Vsr endonuclease (gp48) and dCMP deaminase (gp54 in DLP1, gp55 in DLP2) (Tables 3 and 4; Fig. 5). Three and two additional proteins were assigned putative functions following bioinformatics analysis, in 
Table 3 Bacteriophage DLP1 genome annotation

\begin{tabular}{|c|c|c|c|c|c|c|c|c|c|}
\hline Gene & Start & End & Putative function & Strand & Length (AA) & Closest relative & $\begin{array}{l}\text { Percent } \\
\text { identity }\end{array}$ & Source & $\begin{array}{l}\text { GenBank accession } \\
\text { number }\end{array}$ \\
\hline 1 & 1 & 255 & Hypothetical protein & + & 84 & ORF001 & 100 & PA73 & YP_001293408.1 \\
\hline 2 & 252 & 518 & Holin & + & 88 & Holin & 99 & PA25 & YP_006299866.1 \\
\hline 3 & 511 & 1,056 & Endolysin & + & 181 & Endolysin & 98 & PA25 & YP_006299867.1 \\
\hline 4 & 1068 & 1373 & $\mathrm{Rz}$ & + & 101 & Rz & 99 & Ab26 & YP_009044338.1 \\
\hline 5 & 1288 & 1569 & Rz1 & + & 93 & Rz1 & 100 & PA25 & YP_006299869.1 \\
\hline 6 & 1627 & 2115 & Small terminase & + & 162 & Small terminase & 99 & PA25 & YP_006299870.1 \\
\hline 7 & 2096 & 3691 & Large terminase & + & 531 & Large terminase & 100 & Ab26 & YP_001293413.1 \\
\hline 8 & 3705 & 5210 & Portal protein & + & 501 & Portal protein & 98 & Ab26 & YP_009044342.1 \\
\hline 9 & 5222 & 6316 & $\begin{array}{l}\text { F-like head morphogenesis } \\
\text { protein }\end{array}$ & + & 364 & ORF008 & 100 & PA73 & YP_001293415.1 \\
\hline 10 & 6353 & 7072 & Scaffold protein & + & 239 & Scaffold protein & 100 & PA25 & YP_006299874.1 \\
\hline 11 & 7075 & 8052 & Major capsid protein & + & 325 & ORF010 & 99 & PA73 & YP_001293417.1 \\
\hline 12 & 8122 & 8526 & Hypothetical protein & + & 134 & ORF011 & 100 & PA73 & YP_001293418.1 \\
\hline 13 & 8592 & 8993 & Hypothetical protein & + & 133 & ORF12 & 71 & Ab26 & YP_009044347.1 \\
\hline 14 & 9005 & 9523 & Hypothetical protein & + & 172 & Hypothetical protein & 92 & Ab26 & YP_009044348.1 \\
\hline 15 & 9527 & 9907 & Head-tail joining protein & + & 126 & Hypothetical protein & 98 & PA25 & YP_006299879.1 \\
\hline 16 & 9904 & 10,359 & Minor tail protein & + & 151 & ORF015 & 97 & PA73 & YP_001293422.1 \\
\hline 17 & 10,372 & 11,907 & Major tail tube protein & + & 511 & Major tail tube protein & 99 & PA25 & YP_006299881.1 \\
\hline 18 & 11,971 & 12,399 & Tail chaperonin & + & 142 & ORF017 & 100 & PA73 & YP_001293424.1 \\
\hline 19 & 12,408 & 12,764 & Tail chaperonin & + & 118 & Tail chaperonin & 100 & PA25 & YP_006299882.1 \\
\hline 20 & 12,733 & 13,167 & Hypothetical protein & + & 144 & ORF019 & 100 & PA73 & YP_001293426.1 \\
\hline 21 & 13,173 & 16,708 & Tape measure protein & + & 1175 & Tape measure protein & 96 & PA25 & YP_006299885.1 \\
\hline 22 & 16,701 & 17,663 & Hypothetical protein & + & 320 & Hypothetical protein & 87 & PA25 & YP_006299886.1 \\
\hline 23 & 17,663 & 18,628 & Hypothetical protein & + & 321 & Hypothetical protein & 64 & PA25 & YP_006299887.1 \\
\hline 24 & 18,634 & 20,346 & Hypothetical protein & + & 570 & Hypothetical protein & 96 & PA25 & YP_006299888.1 \\
\hline 25 & 20,346 & 21,170 & Hypothetical protein & + & 274 & Hypothetical protein & 99 & PA25 & YP_006299889.1 \\
\hline 26 & 21,174 & 23,615 & Central tail hub & + & 813 & Central Tail Hub & 99 & PA25 & YP_006299890.1 \\
\hline 27 & 23,616 & 25,667 & DNA polymerase & - & 683 & DNA polymerase & 99 & PA25 & YP_006299891.1 \\
\hline 28 & 25,679 & 26,821 & Replicative clamp & - & 380 & Replicative clamp & 99 & PA25 & YP_006299892.1 \\
\hline 29 & 26,805 & 27,161 & Hypothetical protein & - & 118 & ORF028 & 97 & PA73 & YP_001293435.1 \\
\hline 30 & 27,166 & 28,821 & DEAD box helicase & - & 551 & ORF029 & 100 & PA73 & YP_001293436.1 \\
\hline 31 & 28,814 & 29,911 & RecB exonuclease & - & 365 & ORF030 & 100 & PA73 & YP_001293437.1 \\
\hline 32 & 29,817 & 30,344 & Hypothetical protein & - & 175 & gp055 & 41 & EamP-S6 ${ }^{\mathrm{a}}$ & YP_007005791.1 \\
\hline 33 & 30,423 & 31,169 & Hypothetical protein & - & 248 & $\begin{array}{l}\text { Member of the DUF669 } \\
\text { phage protein family }\end{array}$ & 99 & PA25 & YP_006299897.1 \\
\hline 34 & 31,228 & 31,944 & $\operatorname{Rec} A$ & - & 238 & $\operatorname{Rec} A$ & 99 & Ab26 & YP_009044366.1 \\
\hline 35 & 31,999 & 32,439 & Hypothetical protein & - & 146 & ORF033 & 99 & PA73 & YP_001293440.1 \\
\hline 36 & 32,516 & 33,073 & MazG & - & 185 & MazG & 89 & PA25 & YP_006299900.1 \\
\hline 37 & 33,193 & 33,399 & Transcriptional regulator & + & 68 & ORF035 & 100 & PA73 & YP_001293442.1 \\
\hline 38 & 33,389 & 35,710 & Replicative primase/helicase & + & 773 & Replicative primase/helicase & 99 & PA25 & YP_006299902.1 \\
\hline 39 & 35,862 & 36,062 & Hypothetical protein & + & 66 & Hypothetical protein & 99 & Ab26 & YP_009044372.1 \\
\hline 40 & 36,107 & 36,256 & Hypothetical protein & + & 49 & KAK25_00040 & 96 & PA25 & YP_006299904.1 \\
\hline 41 & 37,055 & 37,234 & Hypothetical protein & + & 59 & Hypothetical protein ORF0038 & 92 & PA73 & YP_001293445.1 \\
\hline 42 & 37,231 & 37,527 & Hypothetical protein & + & 98 & ORF0039 & 98 & PA73 & YP_001293446.1 \\
\hline
\end{tabular}


Table 3 Bacteriophage DLP1 genome annotation (Continued)

\begin{tabular}{|c|c|c|c|c|c|c|c|c|c|}
\hline 43 & 37,524 & 37,703 & Hypothetical protein & + & 59 & Hypothetical protein & 90 & Ab26 & YP_009044375.1 \\
\hline 44 & 37,678 & 37,920 & Hypothetical protein & + & 80 & Hypothetical protein & 96 & Ab26 & YP_009044376.1 \\
\hline 45 & 38,003 & 38,224 & Hypothetical protein & + & 73 & X805_23910 & 56 & DSM $6575^{\mathrm{b}}$ & KDB52021.1 \\
\hline 46 & 38,271 & 38,645 & Hypothetical protein & + & 124 & KAK25_00046 & 99 & PA25 & YP_006299910.1 \\
\hline 47 & 38,706 & 38,927 & Hypothetical protein & + & 73 & KAK25_00047 & 97 & PA25 & YP_006299911.1 \\
\hline 48 & 38,924 & 39,415 & Vsr endonuclease & + & 163 & Vsr endonuclease & 78 & $\mathrm{KL} 1^{\mathrm{c}}$ & YP_006560795.1 \\
\hline 49 & 39,403 & 39,618 & Hypothetical protein & + & 71 & Hypothetical protein & 99 & Ab26 & YP_009044380.1 \\
\hline 50 & 39,615 & 39,794 & Hypothetical protein & + & 59 & KAK25_00050 & 95 & PA25 & YP_006299914.1 \\
\hline 51 & 39,855 & 40,154 & Hypothetical protein & + & 99 & ORF0045 & 81 & PA73 & YP_001293452.1 \\
\hline 52 & 40,171 & 40,461 & Hypothetical protein & + & 96 & ORF0046 & 99 & PA73 & YP_001293453.1 \\
\hline 53 & 40,454 & 40,687 & Hypothetical protein & + & 77 & KAK25_00053 & 100 & PA25 & YP_006299917.1 \\
\hline 54 & 40,983 & 41,450 & $\mathrm{dCMP}$ deaminase & + & 155 & dCMP deaminase & 98 & PA25 & YP_006299919.1 \\
\hline 55 & 41,456 & 41,839 & Hypothetical protein & + & 127 & ORF0050 & 100 & PA73 & YP_001293457.1 \\
\hline 56 & 41,874 & 42,083 & Hypothetical protein & + & 69 & ORF0051 & 96 & PA73 & YP_001293458.1 \\
\hline 57 & 42,167 & 42,739 & Hypothetical protein & + & 190 & ORF0052 & 99 & PA73 & YP_001293459.1 \\
\hline
\end{tabular}

aErwinia phage vB_EamP-S6

${ }^{\mathrm{b}}$ Sphaerotilus natans subsp. natans DSM 6575

${ }^{{ }^{C} \mathrm{KL} 1}$ is Burkholderia phage KL1

DLP1 and DLP2, respectively, based on their high similarities to known proteins: DEAD box helicase (gp30), RecB exonuclease (gp31 - DLP1 only) and a transcriptional regulator (gp37) (Tables 3 and 4; Fig. 5).

BLASTP analysis for DLP1 and DLP2 gp27 shows it is $99 \%$ identical to a putative DNA polymerase in PA25. The replicative clamp of PA25 shares a $99 \%$ identity to gp28 of DLP1 and $95 \%$ identity to gp28 of DLP2. In DLP1, gp31 is $100 \%$ identical to ORF030 in PA73, though its putative function was assigned due to its $95 \%$ identity to the RecB exonuclease of Ab26. Gp31 in DLP2 has $99 \%$ identity to the RecB exonuclease of Ab26. HHpred analysis of the gp31 protein for DLP1 and DLP2 revealed the proteins are similar to the exonuclease of the $\lambda$ Red recombination complex (DLP1: $99 \%$, E-value of $3.8 \mathrm{e}^{-17}$; DLP2: $99 \%$, E-value $5.6 \mathrm{e}^{-17}$ ) [45]. The RecA protein of Ab26 shares $99 \%$ and $100 \%$ identity to the gp34 proteins of DLP1 and DLP2, respectively. The protein gp37 of DLP1 (100\% identity to ORF035 of PA73) and DLP2 (99 \% identity to hypothetical protein in Ab26) have been assigned the putative function of transcriptional regulator due to their similarity to the transcriptional regulator of the Burkholderia phage KL1 [33]. The protein gp38 for both DLP1 and DLP2 shares $99 \%$ identity to the replicative primase/ helicase found in PA25. Both DLP1 and DLP2 contain a Vsr endonuclease (gp48), although gp48 of DLP1 is most similar to KL1 Vsr endonuclease, whereas gp48 of DLP2 is most similar to the $\mathrm{Vsr}$ endonuclease encoded by Ab26 (Tables 3 and 4). The dCMP deaminase (gp54 of DLP1 and gp55 in DLP2) of both phages is most closely related to the dCMP deaminase of PA25 (98 and $97 \%$ identity, respectively). Protein gp30 of DLP1 and DLP2 is $100 \%$ identical to ORF029 of PA73, but a putative function has been assigned in both phages, as gp30 is $99 \%$ identical to the DEAD box helicase protein of Ab26 for both phages. DEAD box helicases are vital in RNA metabolism, as they function to fold RNA molecules into their correct secondary structures and realign RNA-protein interactions with the use of ATP [46].

A predicted protein of interest in DLP1 and DLP2 is MazG, which is encoded by gp36 in DLP1 (89 \% identity to MazG of PA25), and gp36 in DLP2 (98\% identity to MazG of Ab26). During times of stress in bacteria, the unusual nucleotides pppGpp and ppGpp begin to accumulate, synthesized by the proteins SpoT and RelA respectively [47]. Amino acid starvation activates RelA to synthesize ppGpp, whereas other bacterial stressors such as carbon or nitrogen starvation triggers SpoT to synthesize pppGpp $[47,48]$. The pppGpp nucleotide can be converted into ppGpp through the enzyme GppA phosphatase [47]. Both of these unusual nucleotides are involved in the global response to stressful conditions within the bacteria, though ppGpp is a more potent regulatory nucleotide for growth inhibition [47, 49]. MazG fits into this regulatory pathway by depleting the accumulated ppGpp, thus reducing growth inhibition [50]. The action of phage-encoded MazG has been of interest to researchers, as many marine phages have been found to encode MazG homologs [51]. It has been speculated that phage-encoded MazG operates to reduce the ppGpp pool within stationary-phase infected cells [52], thus enhancing propagation of phage progeny in bacterial cells growing in nutrient limiting conditions. 
Table 4 Bacteriophage DLP2 genome annotation

\begin{tabular}{|c|c|c|c|c|c|c|c|c|c|}
\hline Gene & Start & End & Putative function & Strand & Length $(\mathrm{AA})$ & Homologue & $\begin{array}{l}\text { Percent } \\
\text { identity }\end{array}$ & Source & $\begin{array}{l}\text { GenBank accession } \\
\text { number }\end{array}$ \\
\hline 1 & 1 & 255 & Hypothetical protein & + & 84 & $\begin{array}{l}\text { Phage protein found in } \\
\text { lysis cassettes }\end{array}$ & 96 & PA25 & YP_006299865.1 \\
\hline 2 & 252 & 518 & Holin & + & 88 & Holin & 95 & PA25 & YP_006299866.1 \\
\hline 3 & 511 & 1056 & Endolysin & + & 181 & ORF003 & 100 & PA73 & YP_001293410.1 \\
\hline 4 & 1068 & 1373 & $\mathrm{Rz}$ & + & 101 & Rz & 100 & Ab26 & YP_009044338.1 \\
\hline 5 & 1288 & 1569 & Rz1 & + & 93 & Rz1 & 100 & Ab26 & YP_009044339.1 \\
\hline 6 & 1627 & 2115 & Small terminase & + & 162 & Small terminase & 100 & PA25 & YP_006299870.1 \\
\hline 7 & 2096 & 3691 & Large terminase & + & 531 & Large terminase & 99 & Ab26 & YP_009044341.1 \\
\hline 8 & 3705 & 5210 & Portal protein & + & 501 & Portal protein & 99 & Ab26 & YP_009044342.1 \\
\hline 9 & 5222 & 6316 & $\begin{array}{l}\text { F-like head } \\
\text { morphogenesis protein }\end{array}$ & + & 364 & $\begin{array}{l}\text { F-like head morphogenesis } \\
\text { protein }\end{array}$ & 99 & Ab26 & YP_009044343.1 \\
\hline 10 & 6353 & 7072 & Scaffold protein & + & 239 & Scaffold protein & 98 & PA25 & YP_006299874.1 \\
\hline 11 & 7075 & 8052 & Major capsid protein & + & 325 & ORF010 & 99 & PA73 & YP_001293417.1 \\
\hline 12 & 8122 & 8526 & Hypothetical protein & + & 134 & ORF011 & 99 & PA73 & YP_001293418.1 \\
\hline 13 & 8592 & 8963 & Hypothetical protein & + & 123 & ORF012 & 98 & PA73 & YP_001293419.1 \\
\hline 14 & 8976 & 9494 & Hypothetical protein & + & 172 & Virion protein & 100 & PA25 & YP_006299878.1 \\
\hline 15 & 9498 & 9878 & Head-tail joining protein & + & 126 & Virion protein & 98 & Ab26 & YP_009044349.1 \\
\hline 16 & 9875 & 10,330 & Minor tail protein & + & 151 & ORF015 & 99 & PA73 & YP_001293422.1 \\
\hline 17 & 10,343 & 11,878 & Major tail tube protein & + & 511 & Major tail tube protein & 99 & PA25 & YP_006299881.1 \\
\hline 18 & 11,942 & 12,370 & Tail chaperonin & + & 142 & Tail chaperonin & 99 & Ab26 & YP_009044352.1 \\
\hline 19 & 12,379 & 12,735 & Tail chaperonin & + & 114 & Tail chaperonin & 99 & Ab26 & YP_009044353.1 \\
\hline 20 & 12,704 & 13,138 & Hypothetical protein & + & 144 & ORF019 & 100 & PA73 & YP_001293426.1 \\
\hline 21 & 13,144 & 16,711 & Tape measure protein & + & 1187 & Tape measure protein & 99 & PA25 & YP_006299885.1 \\
\hline 22 & 16,709 & 17,671 & Hypothetical protein & + & 320 & Virion protein & 88 & PA25 & YP_006299886.1 \\
\hline 23 & 17,671 & 18,636 & Hypothetical protein & + & 321 & Virion protein & 64 & PA25 & YP_006299887.1 \\
\hline 24 & 18,642 & 20,354 & Hypothetical protein & + & 570 & Virion protein & 96 & PA25 & YP_006299888.1 \\
\hline 25 & 20,354 & 21,178 & Hypothetical protein & + & 274 & Virion protein & 99 & PA25 & YP_006299889.1 \\
\hline 26 & 21,182 & 23,623 & Central tail hub & + & 813 & Central tail hub & 99 & PA25 & YP_006299890.1 \\
\hline 27 & 23,624 & 25,675 & DNA polymerase & - & 683 & DNA polymerase & 99 & PA25 & YP_006299891.1 \\
\hline 28 & 25,687 & 26,829 & Replicative clamp & - & 380 & Replicative clamp & 97 & PA25 & YP_006299892.1 \\
\hline 29 & 26,813 & 27,040 & Hypothetical Protein & - & 76 & KAK25_00029 & 100 & PA25 & YP_006299893.1 \\
\hline 30 & 27,045 & 28,700 & DEAD box helicase & - & 551 & DEAD box helicase & 99 & Ab26 & YP_009044363.1 \\
\hline 31 & 28,693 & 29,790 & RecB exonuclease & - & 365 & RecB exonuclease & 99 & Ab26 & YP_009044364.1 \\
\hline 32 & 29,959 & 30,120 & Hypothetical protein & - & 53 & KAK25_00032 & 100 & PA25 & YP_006299896.1 \\
\hline 33 & 30,302 & 31,054 & Hypothetical protein & - & 251 & $\begin{array}{l}\text { Member of DUF669 } \\
\text { phage protein family }\end{array}$ & 99 & PA25 & YP_006299897.1 \\
\hline 34 & 31,113 & 31,829 & $\operatorname{Rec} A$ & - & 238 & $\operatorname{Rec} A$ & 100 & Ab26 & YP_009044366.1 \\
\hline 35 & 31,884 & 32,324 & Hypothetical protein & - & 146 & Hypothetical protein & 99 & Ab26 & YP_009044367.1 \\
\hline 36 & 32,401 & 32,958 & MazG & - & 185 & MazG & 98 & Ab26 & YP_009044368.1 \\
\hline 37 & 33,078 & 33,284 & Transcriptional regulator & + & 68 & Hypothetical protein & 99 & Ab26 & YP_009044369.1 \\
\hline 38 & 33,274 & 35,595 & Replicative Primase/Helicase & + & 773 & Replicative primase/helicase & 99 & PA25 & YP_006299902.1 \\
\hline 39 & 35,741 & 36,193 & Hypothetical protein & + & 150 & MAM_066 & 54 & DMAM1 $^{\mathrm{a}}$ & YP_007349045.1 \\
\hline 40 & 36,281 & 36,430 & Hypothetical protein & + & 49 & KAK25_00040 & 69 & PA25 & YP_006299904.1 \\
\hline 41 & 36,764 & 36,955 & Hypothetical protein & + & 63 & ORF038 & 94 & PA73 & YP_001293445.1 \\
\hline
\end{tabular}


Table 4 Bacteriophage DLP2 genome annotation (Continued)

\begin{tabular}{|c|c|c|c|c|c|c|c|c|c|}
\hline 42 & 36,952 & 37,248 & Hypothetical protein & + & 98 & ORF039 & 100 & PA73 & YP_001293446.1 \\
\hline 43 & 37,269 & 37,424 & Hypothetical protein & + & 59 & Hypothetical protein & 92 & Ab26 & YP_009044375.1 \\
\hline 44 & 37,399 & 37,641 & Hypothetical protein & + & 80 & ORF040 & 99 & PA73 & YP_001293447.1 \\
\hline 45 & 37,748 & 37,945 & Hypothetical protein & + & 73 & X805_23910 & 58 & DSM $6575^{\mathrm{b}}$ & KDB52021.1 \\
\hline 46 & 37,993 & 38,367 & Hypothetical protein & + & 124 & KAK25_00046 & 97 & PA25 & YP_006299910.1 \\
\hline 47 & 38,428 & 38,649 & Hypothetical protein & + & 73 & KAK25_00047 & 99 & PA25 & YP_006299911.1 \\
\hline 48 & 38,646 & 39,182 & Vsr endonuclease & + & 178 & KAK25_00048 & 100 & PA25 & YP_006299912.1 \\
\hline 49 & 39,170 & 39,385 & Hypothetical protein & + & 71 & Hypothetical protein & 100 & Ab26 & YP_009044380.1 \\
\hline 50 & 39,382 & 39,561 & Hypothetical protein & + & 59 & KAK25_00050 & 98 & PA25 & YP_006299914.1 \\
\hline 51 & 39,622 & 39,927 & Hypothetical protein & + & 101 & ORF045 & 100 & PA73 & YP_001293452.1 \\
\hline 52 & 39,944 & 40,234 & Hypothetical protein & + & 96 & ORF046 & 99 & PA73 & YP_001293453.1 \\
\hline 53 & 40,227 & 40,460 & Hypothetical protein & + & 77 & KAK25_00053 & 99 & PA25 & YP_006299917.1 \\
\hline 54 & 40,531 & 40,698 & Hypothetical protein & + & 55 & ORF048 & 100 & PA73 & YP_001293455.1 \\
\hline 55 & 40,689 & 41,156 & dCMP deaminase & + & 145 & dCMP deaminase & 97 & PA25 & YP_009044383.1 \\
\hline 56 & 41,162 & 41,545 & Hypothetical protein & + & 127 & ORF050 & 100 & PA73 & YP_001293457.1 \\
\hline 57 & 41,580 & 41,789 & Hypothetical protein & + & 69 & ORF051 & 100 & PA73 & YP_001293458.1 \\
\hline 58 & 41,873 & 42,445 & Hypothetical protein & + & 190 & ORF052 & 99 & PA73 & YP_001293459.1 \\
\hline
\end{tabular}

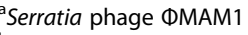

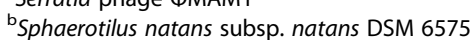

The host bacterium for DLP1 and DLP2, S. maltophilia, has been isolated from nutrient-limited environments, such as ultrapure and deionized water $[2,53]$. The presence of MazG in DLP1 and DLP2 could potentially offer a competitive advantage over MazG-deficient phages replicating in stationary phase $S$. maltophilia.

\section{Phage relatedness}

The two S. maltophila phages DLP1 and DLP2 differ from each other based upon RFLP analysis, DNA comparison analysis, protein:protein comparison analysis, the presence of insertions/deletions (indels), genetic synteny, as well as the phenotypic differences presented, which include different host ranges and the timing of plaque formation. Based upon these analyses, which include changes to both structural and replication genes and their predicted gene products, we conclude that they are significantly different enough in genetic content and biology to be considered individual phages and not merely variants of one another. There is sufficient genomic, proteomic and biological differences that, although they are related phages, DLP1 and DLP2 are not (or are no longer) close variants of each other. These differences include 1369 base pair changes and 157 gaps required to align the DNA, and three genomic locations where DLP1 and DLP2 have acquired completely different genes, which originate from entirely different sources (Additional file 2: Table S2). In DLP1, ORF 32 encodes a protein of 175 amino acids with no known homolog, whereas in DLP2, ORF 32 encodes a 53 amino acid protein that is homologous to a gene found in phage PA25. In DLP1, ORF 39 encodes a 66 amino acid protein without a homolog, whereas DLP2 encodes a protein 150 amino acids in length, also with without known homologs. In DLP2, ORF 55 encodes a 55 amino acid protein that has homologs in both PA25 and PA73, whereas DLP1 has no coding DNA in this region of its genome. Besides these obvious differences, and even though these phages exhibit high average identity across their entire genomes and share almost all proteins, it is still possible that the differences within protein sequences may be associated with the functional differences displayed during bacterial host infection. For example, there are proteins that differ significantly between DLP1 and DLP2 (i.e. a large number of gaps are required to complete alignment), such as ORFs 13, 21, 33, 48, 51 and 54 (encoding a hypothetical protein, a tail tape measure structural protein, a hypothetical protein, a VSR endonuclease replication protein, a hypothetical protein and a dCMP deaminase replication protein, respectively).

Similar to bacterial relatedness, we suggest that phage relatedness is an arbitrary ideal, and that there are no set guidelines as to what constitutes a phage variant versus what is a different but related phage. In order of relatedness, it is clear that DLP1 is most related to DLP2, and then in order of decreasing relatedness, Pseudomonas phages PA25, PA73, Ab26 and finally Burkholderia phage KL1 (Additional file 2: Table S2). Together, they are similar enough to be considered as a Siphoviridae sub-family, but how would one delineate them as 
variants of the same phage versus related phages of a continuum? For example, DLP2 is more related to PA25 circa ORF 32, and more related to PA25 and PA73 circa ORF 55, than DLP1, even though DLP2 shares the most homology with DLP1. Therefore, how much genetic, proteomic and biological differences must be evident before phages are separated into different "species"? Based upon the biological differences (including host range and plaque formation differences), the significant genetic alterations (including the presence of "indels"), and the protein level differences (highly variable but related protein sequences) presented, we conclude that each of these phages are different but related phages. These analyses confirm the idea that, although the phage genome DNA sequences are syntenic, significant changes have occurred between every member of this sub-family of phages, which is also reflected in the biological differences exhibited by phages DLP1 and DLP2.

\section{Conclusions}

Although relatively rare, the incidence of phage broad host range specificity at the genera level is being increasingly studied in the food production industry, mainly with the Salmonella and Escherichia genera [54-57]. This study is the first to identify and characterize phages capable of infecting pathogenic bacteria across taxonomic orders. DLP1 and DLP2 are closely related phages that share a high similarity to $P$. aeruginosa phages vB_PaeKakheti25, vB_PaeS_SCH_Ab26, and PA73 and lesser similarity to Burkholderia phage KL1. Phage DLP1, possessing a 42,887 bp genome, is predicted to encode 57 proteins and exhibits a delayed plaque development phenotype. Unlike DLP1, phage DLP2 exhibits normal plaque development, but possesses a relatively similar genome 42,593 bp in length. The cause of the delayed plaque development in phage DLP1 is yet unknown, but genomic comparison suggests that gene variants encoded by or genes acquired by DLP1 may contribute to the observed lysis phenotype differences. The use of phage therapy may be one of the best treatment options for otherwise untreatable drug resistant bacterial infections $[5,11,58]$. The genomic characterization of broad-host range phages such as DLP1 and DLP2 is the first step towards developing an effective phage therapy strategy for S. maltophilia.

\section{Methods}

\section{Bacterial strains and growth conditions}

Five $S$. maltophilia and eight $P$. aeruginosa strains were acquired from the Canadian Burkholderia cepacia complex Research and Referral Repository (Vancouver, BC). The S. maltophilia strains used for isolation of phage from soil samples were D1585, D1571, D1614, D1576 and D1568. An additional 22 S. maltophilia strains were gifted from the The Provincial Laboratory for Public
Health - North (Microbiology), Alberta Health Services, for host range analysis. All strains were grown aerobically overnight at $30{ }^{\circ} \mathrm{C}$ on half-strength Luria-Bertani $(1 / 2$ LB) solid medium or in $1 / 2$ LB broth with shaking at 225 RPM.

\section{Phage isolation, propagation and electron microscopy}

DLP1 and DLP2 were isolated from Red Deer River sediment and Linum lewisii (blue flax) soil, respectively, using standard extraction protocols [59]. Environmental samples were incubated with shaking at $30{ }^{\circ} \mathrm{C}$ in $1 / 2 \mathrm{LB}$ broth, modified suspension medium (SM) $(50 \mathrm{mM}$ Tris- $\mathrm{HCl}$ [pH 7.5], $100 \mathrm{mM} \mathrm{NaCl}, 10 \mathrm{mM} \mathrm{MgSO}_{4}$ ), and S. maltophlia D1585 liquid culture. Solids were pelleted by centrifugation and the supernatant was filter-sterilized using a Millex-HA $0.45 \mu \mathrm{m}$ syringe driven filter unit (Millipore, Billerica, MA). These were plated in soft agar overlays with strain D1585, and incubated overnight at $30{ }^{\circ} \mathrm{C}$ followed by observation for $>24 \mathrm{~h}$ at room temperature. For each environmental sample, a single plaque was isolated using a sterile Pasteur pipette, suspended in $500 \mu \mathrm{l}$ of modified SM with $20 \mu \mathrm{l}$ chloroform and incubated $1 \mathrm{~h}$ at room temperature to generate stocks for DLP1 and DLP2.

Propagation of the phages was performed using soft agar overlays: $100 \mu \mathrm{l}$ liquid culture and $100 \mu \mathrm{l}$ phage stock were incubated $20 \mathrm{~min}$ at room temperature, mixed with $3 \mathrm{ml} 0.7 \% \frac{1}{1 / 2} \mathrm{LB}$ top agar, overlaid on a plate of $1 / 2 \mathrm{LB}$ solid medium, and incubated at $30{ }^{\circ} \mathrm{C}$ until plaque formation was complete. High titre stocks were made by overlaying plates with confluent lysis with $3 \mathrm{ml}$ modified SM and incubated $>1 \mathrm{~h}$ at room temperature on a platform rocker. The supernatant was recovered, pelleted by centrifugation for $5 \mathrm{~min}$ at 10,000 $\times \mathrm{g}$, filter-sterilized using a Millex-HA $0.45 \mu \mathrm{m}$ syringe-driven filter unit (Millipore, Billerica, MA) and stored at $4{ }^{\circ} \mathrm{C}$. Titre of stocks was obtained using serial dilutions of phage stock into SM, followed by soft agar overlay technique and incubation at $30{ }^{\circ} \mathrm{C}$ until plaque formation was complete.

For electron microscopy, phage stocks were prepared as described above with the following modifications: $1 / 2$ LB agarose plates and $1 / 2$ LB soft agarose were used for overlays, MilliQ-filtered water for phage recovery and a $0.22 \mu \mathrm{m}$ filter was used for syringe-driven filtration. A carbon-coated copper grid was incubated with lysate for 2 min and stained with $4 \%$ uranyl acetate for $30 \mathrm{~s}$. Transmission electron micrographs were captured using a Philips/FEI (Morgagni) transmission electron microscope with charge-coupled device camera at $80 \mathrm{kV}$ (University of Alberta Department of Biological Sciences Advanced Microscopy Facility). The capsid diameter and tail length was calculated using Microsoft Excel based on measurements from nine individual virions. 


\section{Phage host range analysis, and PCR confirmation}

Host range analysis was performed using a panel of 27 clinical S. maltophilia and $19 P$. aeruginosa strains (Tables 1 and 2), and 25 other Pseudomonas and Gramnegative bacterial species (Additional file 1: Table S1). Soft-agar overlays containing $100 \mu \mathrm{l}$ liquid bacterial culture were allowed to solidify for $10 \mathrm{~min}$ at room temperature. These plates were spotted with $10 \mu \mathrm{l}$ drops of DLP1 or DLP2 at multiple dilutions and assayed for clearing (confluent phage lysis), and/or plaque formation after incubation for $36 \mathrm{~h}$ at $30{ }^{\circ} \mathrm{C}$. If plaques were formed, a single plaque from a successful infection plate was picked to propagate as a working stock solution for further analysis. In order to confirm that the plaque contained DLP1 or DLP2 particles, PCR analysis was conducted on each purified phage solution using TopTaq DNA polymerase and buffers (Qiagen) and primers specific to each phage (DLP1F: ACACTGGCGAAGGAT TACGG, DLP1R: GCCTTTCGAAATTCGCCGTT and DLP2F: CGGCTTTTTCGTGCCTGTAA, DLP2R:ACTC CTTTTCGATGCGTCCG) (Sigma-Genosys, Oakville, ON). These PCR products correspond to regions of DNA encoding part of ORF38, ORF39 and ORF40 in DLP1 and part of ORF38 and ORF39 in DLP2. PCR products were separated and visualized on a $1 \%(\mathrm{wt} / \mathrm{vol})$ agarose gel in 1x TAE ( $\mathrm{pH} 8.0$ ), and the product authenticity was confirmed by DNA sequencing. This test is a control experiment designed to ensure that the application of an exogenous phage does not induce a resident prophage into production. All samples that were positive for the production of phage clearing or plaques were subjected to confirmation of DLP1 or DLP2 phage production by PCR.

\section{Phage DNA isolation, RFLP analysis and sequencing}

DLP1 and DLP2 genomic DNA was isolated from bacteriophage lysate using the Wizard Lambda DNA purification system (Promega Corp., Madison, WI) with a modified protocol [60, 61]. A $10 \mathrm{ml}$ aliquot of filtersterilized phage lysate (propagated on D1585 with agarose medium) was treated with $10 \mu \mathrm{l}$ DNase I (Thermo Scientific, Waltham, MA), $100 \mu \mathrm{l}$ 100x DNase I buffer $\left(1 \mathrm{M}\right.$ Tris- $\mathrm{HCl}, 0.25 \mathrm{M} \mathrm{MgCl}_{2}, 10 \mathrm{mM} \mathrm{CaCl}$ ), and $6 \mu \mathrm{l}$ RNase (Thermo Scientific) and incubated $1 \mathrm{~h}$ at $37^{\circ} \mathrm{C}$ to degrade the bacterial nucleic acids. Following incubation, $400 \mu \mathrm{l}$ of $0.5 \mathrm{M}$ EDTA and $25 \mu \mathrm{l}$ of $20 \mathrm{mg} / \mathrm{ml}$ proteinase $\mathrm{K}$ (Applied Biosystems, Carlsbad, CA) were added and incubated $1 \mathrm{~h}$ at $55{ }^{\circ} \mathrm{C}$ to inactivate DNase I. After cooling to room temperature, the lysate was added to $8.4 \mathrm{~g}$ of guanidine thiocyanate, along with $1 \mathrm{ml}$ of $37^{\circ} \mathrm{C}$ resuspended Wizard DNA Clean-Up Resin (Promega Corporation, Madison, WI). This mixture was rocked for $10 \mathrm{~min}$, and then pelleted by centrifugation at room temperature for $10 \mathrm{~min}$ at $5000 \mathrm{x} \mathrm{g}$. The supernatant was drawn off until $\sim 5 \mathrm{ml}$ remained. This mixture was resuspended by swirling, transferred into a syringe attached to a Wizard Minicolumn (Promega Corporation), and pushed through the column. The column was then washed with $2 \mathrm{ml} 80 \%$ isopropanol and dried by centrifugation for $2 \mathrm{~min}$ at 10,000 x g. Phage DNA was eluted from the column following a $1 \mathrm{~min}$ incubation of $100 \mu \mathrm{l}$ of $80{ }^{\circ} \mathrm{C}$ nuclease-free water (Integrated DNA Technologies, Coralville, IA) and centrifugation for $1 \mathrm{~min}$ at 10,000 x g. A NanoDrop ND-1000 spectrophotometer (Thermo Scientific, Waltham, MA) was used to determine purity and concentration of eluted DNA.

For each phage DNA sample, restriction fragment length polymorphism analysis was performed using three - $20 \mu$ l FastDigest EcoRI (Thermo Scientific) reactions containing $1 \mu \mathrm{g}$ of phage DNA. Reactions were incubated at $37{ }^{\circ} \mathrm{C}$ for $5 \mathrm{~min}$ and separated on a $1 \%$ (wt/vol) agarose gel in $1 \mathrm{x}$ TAE (pH 8.0). Preliminary sequencing of EcoRI phage DNA fragments cloned into pUC19 was performed as described previously $[62,63]$. Phage DNA was submitted to The Applied Genomics Core at the University of Alberta for sequencing using MiSeq (Illumina, San Diego, CA) and assembled using the CLC Genomics Workbench (Qiagen, Toronto, ON). The genome sequences of DLP1 and DLP2 have been deposited in GenBank with the accession numbers KR537872 and KR537871, respectively.

\section{Bioinformatics analysis}

Open reading frames (ORFs) for each contig were identified using the GLIMMER plugin [64] for Geneious [65] using the Bacteria and Archaea setting, as well as GeneMarkS (http://exon.gatech.edu/GeneMark/genemarks.cgi) for phage [66]. Conserved domain searches were performed using CD-Search [67]. The contigs were annotated using BLASTN and BLASTP (for full genomes and individual proteins, respectively) [68]. BLASTX and PHAST were used to search for similar sequences in the GenBank database. Sequence comparisons were visualized using Circos (http://circos.ca) [69] and NUCmer (http:// mummer.sourceforge.net) [70] with the following parameters: breaklen $=200$, maxgap $=90$, mincluster $=65$, minmatch $=20$. Lysis protein analysis was performed using TMHMM for transmembrane region identification (http://www.cbs.dtu.dk/services/TMHMM/) [40].

\section{Availability of supporting data}

Supporting data in the form of "Additional file 1: Table S1." can be accessed through LabArchives, LLC at doi: $10.6070 /$ H4CJ8BGT . Supporting data in the form of "Additional file 2: Table S2." can be accessed through LabArchives, LLC at doi: 10.6070/H4H9936J . 


\section{Additional files}

Additional file 1: Table S1. Bacterial Species and Strains Not Sensitive to Phages DLP1 or DLP2. Twenty five different Pseudomonasand other Gram-negative bacteria were tested for sensitivity to phages DLP1 and DLP2 using high- and low-titre plaque overlay assays. None of the additional species or strains were observed to be infected or form plaques under the conditions tested. (DOCX $36 \mathrm{~kb}$ )

Additional file 2: Table S2. Protein: protein comparison of the predicted proteins encoded by phages DLP1 (vB SmaS-DLP 1), DLP2(vB_SmaS-DLP_2), vB_Pae-Kakheti25, vB_PaeS_SCH_Ab26, PA73, and KL1 (vB_Bces_KL1). Pairwise comparison was carried out using BLSATP analysis, and important relationships and descriptivecharacteristics were determined. (DOCX $70 \mathrm{~kb}$ )

\section{Abbreviations}

ATP: Adenosine triphosphate; BLAST: Basic local alignment search tool; bp: Base pair; dCMP: Deoxycytidine monophosphate; DEAD: Asp-glu-ala-asp; DNA: Deoxyribonucleic acid; EDTA: Ethylenediaminetetraacetic acid; FDA: United States Food and Drug Administration; g: Gravitational force or grams; gp: Gene product; h: Hours; kb: Kilobases; kV: Kilovolts; LB: LuriaBertani; M: Molar; min: Minutes; ml: Milliliters; mm: Millimeters; mM: Millimolar; nm: Nanometers; ORF: Open reading frame; PCR: Polymerase chain reaction; RNA: Ribonucleic acid; RPM: Rounds per minute; s: Seconds; SM: Suspension media; TAE: Tris base, acetic acid, EDTA; $\mu$ l: Microliters; $\mu \mathrm{m}$ : Micrometers; vsr: Very short patch repair.

\section{Competing interests}

The authors declare that they have no competing interests.

\section{Authors' contributions}

KHL isolated DLP1 and DLP2. DLP sequenced, annotated and analyzed the genomes, performed electron microscopy and drafted the manuscript. KHL assisted with genome assembly and analysis. PS assisted with the production of Fig. 6. JJD devised the study and assisted with experimental design, data analysis and the writing of the manuscript. All authors read and approved the final manuscript.

\section{Acknowledgements}

The authors would like to thank Arlene Oatway from the University of Alberta Department of Biological Sciences Advanced Microscopy Facility for assistance with electron microscopy, and members of the Dennis lab for helpful scientific discussions. The authors thank the Canadian Burkholderia cepacia complex Research and Referral Repository (CBCCRRR, Vancouver, BC) and The Provincial Laboratory for Public Health - North (Microbiology), Alberta Health Services, for gifts of bacterial strains. JJD gratefully acknowledges operating grant funding from the Natural Sciences and Engineering Research Council of Canada (NSERC).

\section{Author details}

'Department of Biological Sciences, 6-065 Centennial Centre for Interdisciplinary Science, University of Alberta, Edmonton, AB T6G 2E9, Canada. ${ }^{2}$ Department of Agricultural, Food and Nutritional Science, University of Alberta, 1400 College Plaza, Edmonton, AB T6G 2C8, Canada.

\section{Received: 31 March 2015 Accepted: 14 August 2015}

\section{Published online: 03 September 2015}

\section{References}

1. Aarestrup FM, Aidara-Kane A, Sande-Bruinsma N van de, Falzon D, Grundmann H, et al. Antimicrobial resistance: global report on surveillance. World Health Organization; WHO Press, 2014:1-256.

2. Brooke JS. Stenotrophomonas maltophilia: an emerging global opportunistic pathogen. Clin Microbiol Rev. 2012;25:2-41.

3. Waters V, Atenafu EG, Lu A, Yau Y, Tullis E, Ratjen F. Chronic Stenotrophomonas maltophilia infection and mortality or lung transplantation in cystic fibrosis patients. J Cyst Fibros. 2013;12:482-6.

4. Wainwright CE, France MW, O'Rourke P, Anuj S, Kidd TJ, Nissen MD, et al. Cough-generated aerosols of Pseudomonas aeruginosa and other Gramnegative bacteria from patients with cystic fibrosis. BMJ. 2009;64:926-31.
5. Kutter E, De Vos D, Gvasalia G, Alavidze Z, Gogokhia L, Kuhl S, et al. Phage therapy in clinical practice: treatment of human infections. Curr Pharm Biotechnol. 2010;11:69-86.

6. Semler DD, Lynch KH, Dennis JJ. The promise of bacteriophage therapy for Burkholderia cepacia complex respiratory infections. Front Cell Infect Microbiol. 2012;1:27.

7. Hoe S, Semler DD, Goudie AD, Lynch KH, Matinkhoo S, Finlay WH, et al. Respirable bacteriophages for the treatment of bacterial lung infections. J Aerosol Med Pulm Drug Deliv. 2013;26:317-35.

8. Nobrega FL, Costa AR, Kluskens LD, Azeredo J. Revisiting phage therapy: new applications for old resources. Trends Microbiol. 2015;23:185-91.

9. Burrowes B, Harper DR, Anderson J, McConville M, Enright MC. Bacteriophage therapy: potential uses in the control of antibiotic-resistant pathogens. Expert Rev Anti Infect Ther. 2011;9:775-85.

10. Chanishvili N. Phage therapy-history from Twort and d'Herelle through Soviet experience to current approaches. Adv Virus Res. 2012;83:3-40.

11. Seed KD, Dennis JJ. Experimental bacteriophage therapy increases survival of Galleria mellonella larvae infected with clinically relevant strains of the Burkholderia cepacia complex. Antimicrob Agents Chemother. 2009;53:2205-8.

12. Hagens S, Habel A, Ahsen U, von Gabain A. Therapy of experimenta Pseudomonas infections with a nonreplicating genetically modified phage. Antimicrob Agents Chemother. 2004;28:3817.

13. Morello E, Saussereau E, Maura D, Huerre M, Touqui L, Debarbieux L. Pulmonary bacteriophage therapy on Pseudomonas aeruginosa cystic fibrosis strains: first steps towards treatment and prevention. PLoS One. 2011;6(2):e16963.

14. Kumari S, Harjai K, Chhibber S. Bacteriophage versus antimicrobial agents for the treatment of murine burn wound infection caused by Klebsiella pneumoniae B5055. J Med Microbiol. 2011;60:205-10.

15. Waseh S, Hanifi-Moghaddam P, Coleman R, Masotti M, Ryan S, Foss M, et al. Orally administered P22 phage tailspike protein reduces Salmonella colonization in chickens: prospects of a novel therapy against bacterial infections. PLoS One. 2010;5(11):e13904.

16. Golshahi L, Lynch KH, Dennis JJ, Finlay WH. In vitro lung delivery of bacteriophages KS4-M and Î!KZ using dry powder inhalers for treatment of Burkholderia cepacia complex and Pseudomonas aeruginosa infections in cystic fibrosis. J Appl Microbiol. 2011;110:106-17.

17. Semler DD, Goudie AD, Finlay WH, Dennis JJ. Aerosol phage therapy efficacy in Burkholderia cepacia complex respiratory infections. Antimicrob Agents Chemother. 2014;58:4005-13.

18. Wright A, Hawkins $\mathrm{CH}$, Angg Ã $¥ \mathrm{rd} \mathrm{EE}$, Harper DR. A controlled clinical trial of a therapeutic bacteriophage preparation in chronic otitis due to antibioticresistant Pseudomonas aeruginosa; a preliminary report of efficacy. Clin Otolaryngol. 2009:34:349-57.

19. Merabishvili M, Pirnay J, Verbeken G, Chanishvili N, Tediashvili M, Lashkhi N, et al. Quality-controlled small-scale production of a well- defined bacteriophage cocktail for use in human clinical trials. PLoS One. 2009;4:e4944.

20. Rhoads DD, Wolcott RD, Kuskowski MA, Wolcott BM, Ward LS, Sulakvelidze A. Bacteriophage therapy of venous leg ulcers in humans: results of a phase I safety trial. J Wound Care. 2009;18:237-8. 240-3.

21. Abedon ST, Kuhl SJ, Blasdel BG, Kutter EM. Phage treatment of human infections. Bacteriophage. 2011;1:66-85.

22. Chang HC, Chen CR, Lin JW, Shen GH, Chang KM, Tseng YH, et al. Isolation and characterization of novel giant Stenotrophomonas maltophilia phage phiSMA5. Appl Environ Microbiol. 2005;71(3):1387-93.

23. Hagemann M, Hasse D, Berg G. Detection of a phage genome carrying a zonula occludens like toxin gene (zot) in clinical isolates of Stenotrophomonas maltophilia. Arch Microbiol. 2006;185(6):449-58.

24. Chen CR, Lin CH, Lin JW, Chang Cl, Tseng YH, Weng SF. Characterization of a novel T4-type Stenotrophomonas maltophilia virulent phage Smp14. Arch Microbiol. 2007;188(2):191-7.

25. Fan H, Huang Y, Mi Z, Yin X, Wang L, Fan H, et al. Complete Genome Sequence of IME13, a Stenotrophomonas maltophilia bacteriophage with large burst size and unique plaque polymorphism. J Virol. 2012;86(20):11392-3.

26. Huang $Y$, Fan $H$, Pei G, Fan $H$, Zhang Z, An X, et al. Complete genome sequence of IME15, the first T7-like bacteriophage lytic to pan-antibiotic-resistant Stenotrophomonas maltophilia. J Virol. 2012;86(24):13839-40. 
27. Lee CN, Tseng TT, Chang HC, Lin JW, Weng SF. Genomic sequence of temperate phage Smp131 of Stenotrophomonas maltophilia that has similar prophages in xanthomonads. BMC Microbiol. 2014;14:17.

28. Liu J, Liu Q, Shen P, Huang YP. Isolation and characterization of a novel filamentous phage from Stenotrophomonas maltophilia. Arch Virol. 2012;157(9):1643-50.

29. Petrova M, Shcherbatova N, Kurakov A, Mindlin S. Genomic characterization and integrative properties of phiSMA6 and phiSMA7, two novel filamentous bacteriophages of Stenotrophomonas maltophilia. Arch Virol. 2014;159(6):1293-303.

30. GarcÃa P, MonjardÃn C, MartÃn R, Madera C, SoberÃ $\tilde{A}^{3} n$ N, Garcia E, et al. Isolation of new Stenotrophomonas bacteriophages and genomic characterization of temperate phage S1. Appl Environ Microbiol. 2008;74:7552-60

31. Lacroix-Gueu P, Briandet R, LÃ@vÃa que-Fort S, Bellon-Fontaine MN, Fontaine-Aupart MP. In situ measurements of viral particles diffusion inside mucoid biofilms. C R Biol. 2005;328(12):1065-72.

32. Briandet R, Lacroix-Gueu P, Renault M, Lecart S, Meylheuc T, Bidnenko E, et al. Fluorescence correlation spectroscopy to study diffusion and reaction of bacteriophages inside biofilms. Appl Environ Microbiol. 2008;74(7):2135-43.

33. Lynch $\mathrm{KH}$, Stothard $\mathrm{P}$, Dennis JJ. Comparative analysis of two phenotypically-similar but genomically-distinct Burkholderia cenocepaciaspecific bacteriophages. BMC Genomics. 2012;13:223.

34. Sullivan MB, Waterbury JB, Chisholm SW. Cyanophages infecting the oceanic cyanobacterium Prochlorococcus. Nature. 2003;424:1047-51.

35. Watkins SC, Smith JR, Hayes PK, Watts JEM. Characterisation of host growth after infection with a broad-range freshwater cyanopodophage. PLoS One. 2014;9:e87339.

36. Weitz JS, Poisot T, Meyer JR, Flores CO, Valverde S, Sullivan MB, et al. Phagebacteria infection networks. Trends Microbiol. 2013;21:82-91.

37. Karumidze N, Thomas JA, Kvatadze N, Goderdzishvili M, Hakala KW, Weintraub ST, et al. Characterization of lytic Pseudomonas aeruginosa bacteriophages via biological properties and genomic sequences. Appl Microbiol Biotechnol. 2012;94:1609-17.

38. Kwan T, Liu J, Dubow M, Gros P, Pelletier J. Comparative genomic analysis of 18 Pseudomonas aeruginosa bacteriophages. J Bacteriol. 2006;188(3):1184-7.

39. Pellegrin V, Juretschko S, Wagner M, Cottenceau G. Morphological and biochemical properties of a Sphaerotilus sp. isolated from paper mill slimes. Appl Environ Microbiol. 1999;65:156-62.

40. Krogh A, Larsson B, von Heijne G, Sonnhammer EL. Predicting transmembrane protein topology with a hidden Markov model: application to complete genomes. J Mol Biol. 2001;305:567-80.

41. Berry J, Summer EJ, Struck DK, Young R. The final step in the phage infection cycle: the Rz and Rz1 lysis proteins link the inner and outer membranes. Mol Microbiol. 2008;70:341-51.

42. Berry J, Savva C, Holzenburg A, Young R. The lambda spanin components $\mathrm{Rz}$ and Rz1 undergo tertiary and quaternary rearrangements upon complex formation. Protein Sci. 2010;19:1967-77.

43. Summer EJ, Berry J, Tran TAT, Niu L, Struck DK, Young R. Rz/Rz1 lysis gene equivalents in phages of Gram-negative hosts. J Mol Biol. 2007;373:1098-112.

44. Juncker AS, Willenbrock H, Von Heijne G, Brunak S, Nielsen H, Krogh A. Prediction of lipoprotein signal peptides in Gram-negative bacteria. Protein Sci. 2003;12:1652-62.

45. Söding J, Biegert A, Lupas AN. The HHpred interactive server for protein homology detection and structure prediction. Nucleic Acids Res. 2005;33(Web Server issue):W244-8.

46. Owttrim GW. RNA helicases: diverse roles in prokaryotic response to abiotic stress. RNA Biol. 2013;10:96-110.

47. Mechold U, Potrykus K, Murphy H, Murakami KS, Cashel M. Differential regulation by ppGpp versus pppGpp in Escherichia coli. Nucleic Acids Res. 2013;41:6175-89.

48. Magnusson LU, Farewell A, Nyström T. ppGpp: A global regulator in Escherichia coli. Trends Microbiol. 2005;13(5):236-42

49. Maciag M, Kochanowska M, Lyzeń R, Wegrzyn G, Szalewska-Pałasz A. ppGpp inhibits the activity of Escherichia coli DnaG primase. Plasmid. 2010;63:61-7.

50. Gross M, Marianovsky I, Glaser G. MazG - a regulator of programmed cell death in Escherichia coli. Mol Microbiol. 2006:59:590-601.

51. Bryan MJ, Burroughs NJ, Spence EM, Clokie MRJ, Mann NH, Bryan SJ. Evidence for the intense exchange of MazG in marine cyanophages by horizontal gene transfer. PLoS One. 2008;3:e2048.
52. Clokie MRJ, Mann NH. Marine cyanophages and light. Environ Microbiol. 2006:8:2074-82.

53. Arvanitidou M, Vayona A, Spanakis N, Tsakris A. Occurrence and antimicrobial resistance of Gram-negative bacteria isolated in haemodialysis water and dialysate of renal units: results of a Greek multicentre study. J Appl Microbiol. 2003;95:180-5.

54. Matilla MA, Salmond GPC. Bacteriophage ФMAM1, a viunalikevirus, is a broad-host-range, high-efficiency generalized transducer that infects environmental and clinical isolates of the enterobacterial genera Serratia and Kluyvera. Appl Environ Microbiol. 2014;80:6446-57.

55. Bielke L, Higgins S, Donoghue A, Donoghue D, Hargis BM. Salmonella host range of bacteriophages that infect multiple genera. Poult Sci. 2007:86:2536-40

56. Park M, Lee J-H, Shin H, Kim M, Choi J, Kang D-H, et al. Characterization and comparative genomic analysis of a novel bacteriophage, SFP10, simultaneously inhibiting both Salmonella enterica and Escherichia coli 0157:H7. Appl Environ Microbiol. 2012;78:58-69.

57. Kim M, Ryu S. Characterization of a T5-like coliphage, SPC35, and differential development of resistance to SPC35 in Salmonella enterica serovar typhimurium and Escherichia coli. Appl Environ Microbiol. 2011;77:2042-50.

58. Ryan EM, Alkawareek MY, Donnelly RF, Gilmore BF. Synergistic phageantibiotic combinations for the control of Escherichia coli biofilms in vitro. Immunol Med Microbiol. 2012;65:395-8.

59. Seed KD, Dennis JJ. Isolation and characterization of bacteriophages of the Burkholderia cepacia complex. FEMS Microbiol Lett. 2005;251:273-80.

60. DNA isolation from Lambda lysates using the Wizard ${ }^{\oplus}$ DNA Clean-Up System. [http://www.promega.ca/resources/pubhub/enotes/dna-isolationfrom-lambda-lysates-using-the-wizard-dna-cleanup-system/].

61. Lynch KH, Abdu AH, Schobert M, Dennis JJ. Genomic characterization of JG068, a novel virulent podovirus active against Burkholderia cenocepacia. BMC Genomics. 2013;14:574.

62. Lynch KH, Seed KD, Stothard P, Dennis JJ. Inactivation of Burkholderia cepacia complex phage KS9 gp41 identifies the phage repressor and generates lytic virions. J Virol. 2010;84:1276-88.

63. Lynch KH, Stothard P, Dennis JJ. Genomic analysis and relatedness of P2-like phages of the Burkholderia cepacia complex. BMC Genomics. 2010;11:599.

64. Delcher AL, Bratke KA, Powers EC, Salzberg SL. Identifying bacterial genes and endosymbiont DNA with Glimmer. Bioinformatics. 2007;23:673-9.

65. Drummond A, Ashton B, Buxton S, Cheung M, Cooper A, Duran C, et al. Geneious. 2013.

66. Besemer J, Lomsadze A, Borodovsky M. GeneMarkS: a self-training method for prediction of gene starts in microbial genomes. Implications for finding sequence motifs in regulatory regions. Nucleic Acids Res. 2001;29:2607-18.

67. Marchler-Bauer A, Lu S, Anderson JB, Chitsaz F, Derbyshire MK, DeWeeseScott C, et al. CDD: a conserved domain database for the functional annotation of proteins. Nucleic Acids Res. 2011;39(Database issue):D225-9.

68. Altschul S, Madden T. Gapped BLAST and PSI-BLAST: a new generation of protein database search programs. Nucleic Acids. 1997;25:3389-402.

69. Krzywinski M, Schein J, Birol I, Connors J, Gascoyne R, Horsman D, et al. Circos: An information aesthetic for comparative genomics. Genome Res. 2009;19:1639-45.

70. Delcher AL, Phillippy A, Carlton J, Salzberg SL. Fast algorithms for large-scale genome alignment and comparison. Nucleic Acids Res. 2002;30:2478-83.

\section{Submit your next manuscript to BioMed Central and take full advantage of:}

- Convenient online submission

- Thorough peer review

- No space constraints or color figure charges

- Immediate publication on acceptance

- Inclusion in PubMed, CAS, Scopus and Google Scholar

- Research which is freely available for redistribution 